\title{
From Interdisciplinarity to Transdisciplinarity in Translation Studies in the Context of Technological Tools \& Localization Industry
}

\author{
Mehmet Cem Odacioğlu \\ Dept. of Translation Studies, Sakarya University, Turkey \\ Şaban Köktürk \\ Dept. of Translation Studies, Sakarya University, Turkey
}

Received: 15-04-2015

doi:10.7575/aiac.ijclts.v.3n.3p.14
Accepted: 15-06- 2015

Published: 31-07- 2015

\begin{abstract}
Having long been accepted by many translation scholars as an interdisciplinary field, Translation Studies is now thought to be a maturated discipline with the advent of new technological tools or the integration of computerized devices into the translation practice. The interdisciplinary aspect of Translation Studies generally stems from linguistics, philology, philosophy, sociology and cultural studies. Additionally, most translation scholars explain the interdisciplinarity of Translation Studies according to these fields of study. However, as explained above, there are also technological tools or computerized devices that contribute to the maturation of Translation Studies and are supported by the integrated computer technologies associated with computational linguistics, computer engineering, software engineering and so forth. This fact brings to the mind a new concept, i.e trans-disciplinarity, which is seldomly mentioned in Translation Studies. This study therefore investigates "trans-disciplinarity" within Translation Studies by connecting it with technology integrated tools commonly used in the translation practice. From this point of view, the study questions whether these tools or computerized devices contribute to the transition process from inter-disciplinarity to trans-disciplinarity in Translation Studies.
\end{abstract}

Keywords: Transdisciplinarity, interdisciplinarity, translation studies, technological tools, transdisciplinary, interdisciplinary

1. Introduction

Holmes's seminal paper "The Name and Nature of Translation Studies" (1972) which he presented in the Third International Congress of Applied Linguistics is regarded as the founding statement of a new discipline, (Munday, 2008:9). This work is the first move to make Translation Studies a discipline which is later transformed into an interdisciplinary field with the presence of linguistics, philology, philosopy, sociology and so forth. Even today, this interdisciplinary aspect of Translation Studies is put forward by translation scholars. However, science is never static and it must be open to dynamic changes or the birth of new areas of study. From this point on, especially with the advent of technological tools as a result of the development in computer programming, computer engineering, software engineering and so forth, the inter-disciplinary characteristics of Translation Studiesmust be discussed and whether Translation Studies starts showing a trans-disciplinary tendency or not must be pondered. There has always been turns changing from linguistic to culture and and now to technology in Translation Studies (see Cronin, 2010, see SnellHornby, 2006). First, the paradigm of Translation Studies was accepted as linguistic oriented translation approaches, then replaced by functional translation theories such as Vermeer's "Skopos Theory", Mänttäri's "Translational Action Theory" and, later Descriptive Translation Studies as well as cognitive approaches were also accepted as paradigms. These developments were generally associated with the inter-disciplinary characteristics of Translation Studies. However, the extension of Translation Studies is now large thanks to the popularization of computers to home users as of 1980s and especially the birth of the localization industry. In this case, the traces of Translation Studies can be followed into the computerized sciences. Translators have now given up using written based dictionaries and old fashioned type-writers. Instead, they are now using state-of-art computer technologies reinforced by IT and computer specialists. For the sustainability of the maturation of Translation Studies, a new concept can therefore be suggested: "trans-disciplinarity" to explain the fact that Translation Studies is more inclusive apart from linguistic, philology, philosophy andculturebased approaches, which brings to the mind ICT technologies. Transdisciplinarity is "a different manner of seeing the world, more systemic and more holistic" (Max Neef, 2005:15). Transdisciplinarity transgresses boundaries. Its potentiality serves to acquire a better outcome or to produce a better science (see Nowotny, 2006).

\footnotetext{
${ }^{1}$ This term was invented by Jean Piaget seven centuries after disciplinarity had evolved (see Nicolescu, 2010:19). In connection, Piaget states that "finally, we hope to see succeeding to the stage of interdisciplinary relations a superior stage, which should be 'transdisciplinary,' i.e. which will not be limited to recognize the interactions and/or reciprocities between the specialized researches, but which will locate these links inside a total system without stable boundaries between the disciplines" (qtd. Nicolescu, 2010: 20).
} 
Boundaries for Translation Studies, stem as far as we believe, from linguistic, philological, philosophical, sociological and cultural fields. However, we now live the digital age which requires the extension of borders in Translation Studies by integrating technological tools and computerized solutions. Therefore, even though some of the translation scholars still regardTranslation Studies as an inter-disciplinary field today by even taking into account new technological areas within TS, we claim ${ }^{2}$ that its inter-disciplinary aspect must now be replaced by trans-disciplinarity ${ }^{3}$, if it wants to sustain its dynamism and maturation especially in the context of the technology.

\subsection{Research Questions}

To make our claim sound, the study centres upon the following research questions:

1. In the light of the developments in the field of ICT (Information and Communication Technologies), what is the position of Translation Studies today?

2. What can be the effects of technological tools on Translation Studies in its possible transition process from inter-disciplinary to trans-disciplinary?

3. What can be the effect of the Localization Industry on Tranlation Studies in its possible transition process from inter-disciplinary to trans-disciplinary?

\subsection{Literature Review}

The present study coincided with only one source regarding Translation Studiesin which "trans-disciplinary" concept is found (See Yazıc1's Çeviri Bilimde Araştırma/ Research in Translation Studies, 2011). Then, it can be argued that most books or papers on translation studies have dealt with "interdisciplinary" concept so far. In the field of of translation technology and localization industry, there are lots of papers and books in theoretical and practical frameworks (see Pym, Austermüehl, Dunne, Esselink, O’Hagan, Sin Wai, Mangiron, Sikes, Schäler, Sandrini, Mullama, Mazur, Malmkjaer, Lommel, Kosaka, Itagaki, Jiménez Crespo, Garcia, Raído, Dillinger, Bowker, Biau Gil, Bernal Merino, Archer, Altanero and so forth). As a result of the analysis, we have, however,seen that most translation scholars and translation practitioners have focused on inter-disciplinary aspect of Translation Studies in their works. Therefore, this study aims to justify the maturated position of Translation Studies and to increase its legitimacy more by defending “trans-disciplinarity”(see Holmes 1972, Munday, 2008, Yazıc1, 2011, Şan, 2014).

\section{From Inter-Disciplinarity to Trans-Disciplinarity in Translation Studies}

Transdisciplinarity is regarded by Mittelstrass "as the further development of inter-disciplinarity" (2011: 329). Though this term is generally associated with "environmental, energy and health care policy problem" (see Mittelstrass, 2011), it can also be applied to Translation Studies, one of the branches of social sciences whose scientific legitimacy has already been approved. Transdisciplinarity concept is "a principle of research and science, one which becomes operative wherever it is impossible to define or attempt to solve problems within the boundaries of subjects or disciplines, or where one goes beyond such definitions" (Mittelstrass, 2011: 331). In the digital revolution, the position of Translation Studies with its inter-disciplinary aspect can remain insufficient to solve technology driven problems or its classical tools may not be adequate to support empirical studies, for example in electronic corpora research (see, for insance, Crespo) encouraged by the digital technologies. Pym, in an interview also states that "Translation Studies as an inter-discipline connected with many other disciplines, is not well suited to specialization" (2013: 61). We think Pym, in this statement implies that current Translation Studies does not meet the criteria of some special fields of translation, implicitly technical field requiring the extensive use of the technology that is hugely based on today's productive localization market. This fact calls for the emphasis of the transdisciplinarity concept and evokes the necessity that new paradigm shifts in Translation Studies must be sought in the context of digital solutions.

The transition from inter-disciplinarity to trans-disciplinarity in Translation Studies can be laid a foundation by beginning from translation courses because translation is first of all a practice and digital solutions are available for translators only to make their tasks easy and productive. Without receiving a good education, the appropriate use of digital technologies may not be acquired well or translators might be forced to be specialized at these tools in the professional environments after they graduate with no knowledge over them. Then, to change something must begin from changing the way translation is done and this is firstly possible in computerized translation classrooms. To introduce trans-disciplinarity into Translation Studies, this is the first step to take. Then, translators must get accustomed to using CAT tools which are also used by professional translators on the real time translation/localization markets. In this regard, the sub-headings below include translation memories, electronic corpora, terminology databases, online dictionaries and an umbrella term all of which foreground the trans-disciplinarity of Translation Studies. Especially the preparation of technological tools is undertaken by experts in computer sciences and, translators as well their linguistic and cultural competences, when using these tools are expected to use computer well and even to know programming and engineering related tasks in computerized settings for speedy and productive translations. These facts contribute to the transgression of borders in Translation Studies, making it trans-disciplinary.

\subsection{Translation Memories}

Translation memories are one of the most important CAT tools for translators, especially in extensive localization projects. While the translator is translating, the translated terms get stored in a database and in similar projects these stored terms in translation memories are displayed to translators for reuse, without having to translate it again (see Hatim and Munday, 2004:114). Such tools present translators full matches or fuzzy matches in the translation process and force them to do translation segment by segment or a decontextualized translation(see Pym, 2011). Though this

\footnotetext{
${ }^{2}$ This study was designed as a reflective writing taking into account the latest technological innovations and their effects in Translation Studies as well as the definition of transdisciplinarity, i.e the transgression of the available borders in a science " to produce a better outcome" (see Nowotny, 2006).

${ }^{3}$ This word can now be said to be a highly ostentatious for Translation Studies but we belive that the shift from interdisciplinarity to transdisciplinarity is required to further show the legitimacy of Translation Studies in the scientific respect.
} 
seems disadvantegous and boring, the translation of technical texts is generally word for word or literal. That's why what is important here is to transmit the content in an accurate, concise and productive way. Translation memories with their productice abilities accelerate the translation process and besides facilitate the burden of translators. In addition, translation memories can be formed either in the translation process or after the translation is done using an alignment tool. Perhaps one of the reasons why professional translators on the market are attracted to translation memories is that they can use their previous translations in every translation project (Austermüehl and Raído, 2003: 235-236). Prominent translation memories can be listed as SDL Trados Studio 2015, Transit NXT (next generation), Atril's Déjàvu and Champollion's Wordfast.

\subsection{Electronic Corpora}

In Oxford Dictionary, corpus is defined as "a collection of written texts, especially the entire works of a particular author or a body of writing on a particular subject" (http://www.oxforddictionaries.com/definition/english/corpus).In some resources, it is asserted that corpus is now related to a computer database. However, Bernardini and Castagnoli define electronic corpora distinctly as the collection of texts in electronic forms generally grouped by taking into account the topic, type, contract and business letter, etc (Bernardini and Castagnoli, 2008: 45). This tool is useful for translators in the translation process to understand the context. Also, it is generally used for linguistic resarch and today especially corpus based research is regarded as one of the paradigms in Translation Studies. The Corpus of Contemporary American English (http://corpus.byu.edu/coca/), British National Corpus (http://www.natcorp.ox.ac.uk/), Cambridge English Corpus (http://www.cambridge.org/us/cambridgeenglish/about-cambridge-english/cambridgeenglish-corpus) are some of the examples of electronic corpora which can be accessed through internet.

\subsection{Terminology Databases}

Terminology databases are one of the leading digital solutions to translators in the translation process to alleviate the translator's burden and facilitate the translational action. Terminology databases store terms and translators benefit from them in each translation process without the need for further translation. Terminology databases are used for many purposes. Translators, especially working in international organizations frequently use such terminology databases as IATE (Inter-Active Terminology for Europe), Europe Term Bank, Eurovoc (EU's Multilingual Thesaurus), UnTerm (United Nations Multilingual Terminology Database), FAOterm (Food and Agriculture Organization of the United Nations), UNESCOterm, UNHCR (The International Thesaurus of Refugee Terminology), WTOterm (World Trade Organization), OECD Terminology (Organization for Economic Cooperation and Development), ILOterm (International Labour Organization), Lexicool (Nato terminology) (see http://termcoord.eu/useful-links/terminologydatabases/)and so forth. Apart from these databases, translators can also use special terminology databases on localization markets for productive and fast translations. Such tools can store terms related to the same subject matter, equivalent phrases in a language or more than one language, synonymous words and contexts (seeBowker, 2002:51).The logic behind terminology databases is the same as translation memories. It contributes to the translation process by accelerating the translation task and as a result productivity enhances.

\subsection{Online Dictionaries}

Online dictionaries can easily be accessed through a network technology, with a computer and a modem. Translators before the creation of online dictionaries would use CD-Rom based versions whose updates can be challenging. However, with the advent of the internet and the need for translation has increased day by day as a result of the digital revolution, dictionary producers have started to show a tendency towards virtual dictionaries whose accessions are mostly free and which can be fast updated without too much cost. Now the paper dictionaries are replaced by their virtual counterparts and translators do not lose time without having to turn over pages, which means productivity in the translation process. Here is the table of some online dictionaries:

Table 1. Online Dictionaries ${ }^{4}$

\begin{tabular}{|c|c|}
\hline Online Dictionaries & Website Adress \\
\hline Merriam Webster & http://www.merriam-webster.com/ \\
\hline Longman: Dictionary of Contemporary & http://www.ldoceonline.com/ \\
\hline English & \\
\hline Oxford Dictionaries: Language matters & http://www.oxforddictionaries.com/ \\
\hline The Free Dictionary & http://www.thefreedictionary.com/ \\
\hline Macmillan Dictionary & http://www.macmillandictionary.com/ \\
\hline Collins French Dictionary & $\begin{array}{l}\text { http://www.collinsdictionary.com/dictionary/english- } \\
\text { french }\end{array}$ \\
\hline Spanish D!ct & http://www.spanishdict.com/ \\
\hline Collins Italian Dictionary & $\begin{array}{l}\text { http://www.collinsdictionary.com/dictionary/english- } \\
\underline{\text { italian }}\end{array}$ \\
\hline BeoLingus: Your Online Dictionary & http://dict.tu-chemnitz.de/ \\
\hline Word Dictionary & http://www.mdbg.net/chindict/chindict.php \\
\hline Jisho & http://jisho.org/ \\
\hline Zkorean & https://www.zkorean.com/english-korean-dictionary \\
\hline Turkish Dictionary & http://www.turkishdictionary.net/ \\
\hline
\end{tabular}

${ }^{4}$ French, Italian, German, Spanish (FIGS), English, Chinese, Korean, Japanese, Turkish Dictionaries are listed in the table. 


\subsection{Localization Industry}

The above mentioned translation tools have come out as the result of the rise of translation technologiesespecially as of 1980s due to the fact that computer prices fell and they were spread to ordinary home users apart from the academic and professional circle. This increased the demand for softwares in every region of the world. In connection, computer companies such as Sun Microsystems and Microsoft which have been mostly located in the USA started producing their software products for international markets. This meant the need for localizing ${ }^{5}$ the products into many languages at the same time to encourage the simship or in other words simultaneous shipping for productive and fast translations without no delay because any delay in the release of the product meant a financial loss for a company (Esselink, 2006: 22).

As known, localization is defined by LISA as "taking a product and making it linguistically and culturally appropriate for the target locale (country/region/language) where it will be used and sold"(qtd. Esselink, 2000:3 from LISA).The driving force behind the localization industry according to Pym is the internationalization step, which means "the process of generalizing a product so that it can handle multiple languages and cultural convention without the need for re-design. It takes place at the level of program design and document development" (qtd. Pym, 2010: 122). In connection with this, Pym also asserts that in localization, unlike the traditional translation defending a move from a source to the target text, there is a move from a source to a general intermediary version, which brings to mind the internationalization step. This step is taken to facilitate the translation task or in other words the localization task. In this way, the unexpected problems may be eradicated before the release of the localized products into international markets. Then, it can be stated that without internationalization, localization is impossible.

Every step in the localization process is taken and decisions are made in accordance with the coordination of an extensive team work. The team members change from a project manager, desktop publisher, localization engineer, graphic designer, and technical expert to translator in action, linguists and other senior translators to revise the localization project. Esselink in his book A Practical Guide to Localization (2000) specifies some steps in localization projects in a following manner:

\section{Project Managing}

2. Step of Translation and Engineering of Software,: website or localizable contents

3. Step of Translation and Desktop Publishing of Documentation

4. Step of Translation and Assembling of Multi-Media or Computer Based Training Components

5. Step of Functionality Testing of Localized Content: software, game or web localization (See Esselink, 2000)

Each of the steps above are taken coordinately and thus self control by the team members is enabled, which means that the responsibility of the localization workflow system is shared by everyone though every localization project may differ to an extent. At this point it can in parallel be said that such a workflow system (see Esselink, 2000) foregrounds a collaborative approach which is rarely available in the individual translation task. This collaborative approach enables the translation to be speedy and consistent. This means that companies desiring to market their products in other countries gain profit and even the low quality products primarily manufactured for national borders may be hugely sold to other countriesthanks to the collaborative feature of localization projects. It can here be said that this term, collaboration can contribute to the transdisciplinarity of Translation Studies. Especially, one of the functional translation theories, Skopos Theory by Vermeer (1984) puts forward that "the translator is responsible for the performance of the comissioned task, for the final translation" (Vermeer, 2000: 222). This statement indeed gives the impression that the translator as the primary expert in the translation process is isolated from the other specialists though he/she sometimes makes contact with area specialists. However, in localization workflow systems, the key term is the "synchronic collaboration". Every actor in each steps takes reponsibility and undertakes the assigned task in a coodinative way. Their background comes from different specializations and everybody is the expert in their tasks. In connection, the relationship between each actor in the localization workflow system can imply that there is a transdiciplinary approach since all the elements of computer engineering, software engineering, graphic designing, language and technical processing and dekstop-publishing can be traced throughout the project. The translation activity in the technological agenecessitates the transgression of borders within Translation Studies and this means transdisciplinary, as repeatedly stated. According to Turkish translation scholar Yazıc1, disciplines evolve by extending their research methods to inter-disciplinary, multi disciplinary and trans-disciplinary studies and Translation Studies must keep pace with this process to increase its legitimacy (2011:163). Today, Translation Studies, as far as we claim, is on the way to trans-disciplinary research and this is well observed in the localization field. For Instance, Crespo in his paper entitled "A Corpus Based Error Typology: Towards a More Objective Approach to Measuring Quality in Localization" suggests a corpus based approach which is more associated with ampiricism in order to evaluate the translation in terms of measuring the quality (2011). Such researches in the localization field lay a foundation for transdisciplinarity of Translation Studies ${ }^{6}$.

\section{Conclusion}

The Study has questioned the current status of translation studies by taking into account the latest technological developments and the popularization of the localization industry as of 1990s. All technological tools having been

\footnotetext{
${ }^{5}$ In February 2015, the authors also presented "The Effects of Technology on Translation Students in Academic Translation Teaching" in the 7th World Conference on Educational Sciences, held in Greece. The similar information on localization can also be found there.

${ }^{6}$ The theoretization studies of localization (see Pym) today have a very important position for the legitimacy of trans-disciplinary concept in Translation Studies.
} 
mentioned so far are translational aids brought by the digital age to the translator. By learning how to use these electronic tools, translators must now get used to the logic of the translation technology and to do so, they must at least know how to use computer to maximize the productivity of the translational action. On the other hand, If they force themselves to understand computer programming and engineering even on a minimum level, the productivity which is now one of the key words for all localization projects will certainly increase. Translators, in doing so, carry the translation to trans-disciplinary journey or least they can be helpful in this regard.

Additionally, the umbrella term "localization industry" includes all the technological tools listed in this study and besides it requires an extensive team work in localization projects. This means that the translational activity is any longer not an isolated individual task and decisions are taken by group members mutually. In parallel, the translator is now not the single expert in the translation process. His/her responsibility is interactively shared by other professionals coming from different backgrounds such as computer engineering, software engineering, graphic designing, desktop publishing and so forth. This brings to the mind a new collaboration approach to the translation practice supported by a network technology. With this new approach, the translation is carried out by taking into accountother fields of expertisein the localization project. At this point it should alsobe remembered that localization projects also include computer engineering related tasks and issues on computer technologies. With the addition of these fields of study to the translation, Translation Studies can be asserted to pave way for trans-disciplinary approaches and researches, besides it is on the journey from inter-disciplinarity to trans-disciplinarity.

Last but not least, Translation Studies is currently thought to show a transition process from inter-disicplinarity to transdisicplinarity because of the integration of ICT into the translation field, the effect of technologies tools on Translation Studies and the presence of the Localization industryin general because all of these contribute to the transgression of former borders in the translation field as summarized in the study.

\section{References}

Basil, H. Ve Munday J. (2004).Translation, An Advanced Resource Book. London and New York: Routledge (Taylor\&Francis Group).

Bernadini, S. \& Castagnoli S. (2008). Corpora for translator education and translation practice.In E. Y. Rodrigo (Ed.), Topics in Language Resources for Translation amd Localisation, 39-55.Amsterdam and Philadelphia: John Benjamins Publishing Company.

Bowker, L. (2002). Terminology Tools for Translators. Computers and Technology: A Translator's Guide, (Ed. Harold Somers) 49-65.Philadelphia: John Benjamins Publishing Company.

Cronin, M. (2010). The Translation Crowd.Traducció i la Communicació, 8, 1-7.

Jiménez-Crespo, M.A. (2011). A Corpus Based Error Typology: Towards a More Objective Approach to Measuring Quality in Localization.Perspective Studies in Translatology 19:4, 315-338. London and New York: Taylor and Francis.

Enríquez Raĺdo, V. and Austermuhl, F. (2003).Translation, Localization and Technology-Current Developments.Speaking in Tongues: Language across Context and Users (ed. Luis Pérez Gonzáles), 225-248.Valéncia, Spain:Universitat de la.

Esselink B. (2006). The Evolution of Localization. In A. Pym, A. Perekrestkenko\& B. (Eds.),Translation Technology and Its Teaching, 21-29. Universitat i Virgili: Inter Cultural Studies Group.

Esselink, B. (2000).A Practical Guide to Localization.Amsterdam/Philadelphia:John Benjamins Publishing Company.

Max-Neef, Manfred A. (2005).Foundations of Transdisciplinarity. Ecological Economies 53, 5-16.

Mittelstrass, J. (2011). On Transdisciplinarity.Trames, 15(65/60), 329- 338.

Munday, J. (2008).Introducing Translation Studies: Theories and Applications (Second Edition).London and New York: Routledge.

Nowotny, H. (2006).The Potential of Transdisciplinarity. http://www.helganowotny.eu/downloads/helga_nowotny_b59.pdf. Accession Date: 12.05.2015.

Nicolescu, B. (2010).Methodology of Transdisciplinarity- Levels of Reality, Logic of the Included Middle and Comlexity. Transdisciplinarity Journal of Engineering \& Science, 1(1), 19-38.

Pym, A.(2010). Exploring Translation Theories, London and New York:Routledge.

Pym, A. (2011). Website Localization. The Oxford Handbook of Translartion Studies (eds. Kirsten Malmkjaer and Kevin Windle), 274-283. Oxford University Press.

Pym, A. (2013).Translation Technology and Translation Theory: Dialogue with Anthony Pym on Localization. Chinese Translators Journal, 4, 61-64.

Snell-Hornby, M. (2006).The Turns of Translation Studies. Amsterdam and Philadelphia: John Benjamins Publishing Company.

Şan, F. (2014). Disiplinlerarasılık Açısından bir Bilim Dalı Olarak Çeviri (Translation Studies in terms of Interdisciplinarity) (PHD Thesis). Sakarya Üniversitesi Sosyal Bilimler Enstitüsü: Sakarya. 
IJCLTS 3 (3):14-19, 2015

Vermeer, H J. (2000). Skopos and Commmission in Translational Action, (translated by A. Chesterman), In L. Venuti (Ed.).Translation Studies Reader, 221-232.London and New York: Routledge.

Yazıc1, M. (2011).Çeviribilimde Araştırma (Research in Translation Studies).İstanbul: Multilingual.

http://www.oxforddictionaries.com/definition/english/corpus Accession Date: 14.05.2015.

http://termcoord.eu/useful-links/terminology-databases Accession Date: 14.05.2015. 